\title{
QUANTIFYING THE INFLUENCE OF SINKHOLES ON WATER BALANCE IN IRAN'S GOLGIR ALLUVIAL PLAIN
}

\author{
TOURK-QASHQAINEJAD, S. ${ }^{1}-$ CHITSAZAN, $M{ }^{1 *}{ }^{*}-$ ADAMOWSKI, J. ${ }^{2}$ \\ ${ }^{I}$ Department of Geology, Faculty of Earth Sciences, Shahid Chamran University, Ahvaz, Iran \\ ${ }^{2}$ Department of Bioresource Engineering, McGill University \\ Sainte-Anne-de-Bellevue, Quebec, H9X 3V9, Canada \\ *Corresponding author \\ e-mail: Saeedhydro@gmail.com \\ ( phone+98-615-33360018; fax:+98-615-33332618) \\ (Received 26 ${ }^{\text {th }}$ Jan 2017; accepted 23 ${ }^{\text {rd }}$ Mar 2017)
}

\begin{abstract}
Southwestern Iran's Golgir plain lies on chalky bedrock made up of Tertiary gypsum surrounded and covered by thin Quaternary deposits. Since the onset of the new millennium, this region and its farmland has been prone to land depression and other instability phenomena linked to gypsum dissolution. A simple water balance over the period of 2005 to 2012 was employed to assess the role of sinkholes in these phenomena. Geological and geophysical features as well as initial water balance calculations confirmed the presence of sinkholes and their influence in the study area. A significant discrepancy $\left(2.55 \times 10^{6} \mathrm{~m}^{3}\right)$ was observed between annual estimates of water inputs and discharge from the region, likely attributable to errors in identifying and quantifying output components. A bedrock map derived from geophysical investigations and the geological characterization of the chalky bedrock showed that, in comparison to the local groundwater table, there was a roughly $40 \mathrm{~m}$ drawdown towards the location of sinkholes. Groundwater inflow towards the aquifer was revised so as to include an identified sinkhole output component in the water balance equation, resulting in a much greater accuracy in the annual water balance estimates. Estimated annual recharge volumes ranged from $4.39 \times 10^{6}$ to $7.15 \times 10^{6} \mathrm{~m}^{3}$, with a mean of $5.64 \times 10^{6} \mathrm{~m}^{3}$. The water balance equation was shown to constitute a simple, cost-effective, and reliable approach to the recognition and evaluation of sinkholes in areas under similar conditions.
\end{abstract}

Keywords: chalky bedrock, groundwater recharge, hydrogeology, sinkhole, water management

\section{Nomenclature}

A Area of the aquifer

$\mathrm{m}^{3} \quad$ Cubic meter

$\mathrm{mm} \quad$ Millimeter

ESL Envelope Straight Line

GIS Geographic Information System

$\mathrm{I}_{\mathrm{G}} \quad$ Subsurface input water from aquifer boundaries

$\mathrm{I}_{\mathrm{IRF}} \quad$ Infiltration volume from irrigation return flow

$I_{P} \quad$ Infiltration volume from precipitation

$I_{R} \quad$ Infiltration volume from runoff

I $\quad$ Infiltration volume from industry and domestic wells

$\mathrm{O}_{\mathrm{D}} \quad$ Output volume from the aquifer system by drainage into the river

$\mathrm{O}_{\mathrm{Sh}} \quad$ Output volume from the sinkhole

$\mathrm{O}_{\mathrm{ET}} \quad$ Output volume from the aquifer system by evapotranspiration

$\mathrm{O}_{\mathrm{G}} \quad$ Subsurface output water from aquifer boundaries

$\mathrm{O}_{\mathrm{w}} \quad$ Output volume from the aquifer system by well pumping

PET Potential of evapotranspiration

Sy Specific Yield

WBE Water Balance Equation

$\Delta \mathrm{H} \quad$ Changes in groundwater level

$\Delta \mathrm{S} \quad$ Changes in saturated groundwater storage

$\Sigma \mathrm{I} \quad$ Sum of the Input Components

$\Sigma \mathrm{O} \quad$ Sum of the Output components 


\section{Introduction}

Given its pivotal role as a major water resource in arid and semiarid regions, groundwater is of particular concern to such regions' water resource managers and hydrogeologists, both in terms of their quality and availability (Jiang et al., 2009; Bain et al., 2014). In arid and semiarid regions, such as Iran, groundwater is considered one of the few reliable resources of water available to communities where population growth and intense water usage result in water scarcity, particularly of drinking water (Girman et al., 2007).

Different portions of gypsum deposits are characterized by a variety in lithological composition (e.g. Testa and Lugli, 2000; Gündogan et al., 2005; Schreiber et al., 2007) and texture (e.g. Gündogan et al., 2008; Hildyard et al., 2009). The complexity of alternating gypsum, limestone, sand, gravel and clay layers, as well as the presence or absence of an intergranular matrix is the result of both chemical and physical conditions of the evaporitic sites of deposition, and the subsequent diagenetic mineral transformations mediated by tectonics, burial, exhumation and weathering processes (Festa et al., 2016).

Depressions or outright holes in the surface of alluvial terrain, sinkholes occur when soils or other surface deposits overlying karstic rocks collapse into conduits enlarged by dissolution (Soriano and Simon, 1995). A number of factors may operate in concert in the development of alluvial sinkholes, amongst which Soriano and Simon (1995) distinguish three main groups: physical (substrate solubility, lithology and land cover), hydrological (water infiltration, hydraulic gradient, depth and seasonal variations of the water table, chemical composition of groundwater) and human factors (irrigation, pumping, construction). These factors' influence on sinkhole formation occurs primarily through either:

(i) the evacuation of material through the subsoil, a process tied to infiltration rate, subsurface flow and chemical composition of water, bedrock solubility, and the capacity for movement of sediment-sized particles, or

(ii) the probability of collapse or subsidence of the cover, a process tied to lithology, geomechanical behaviour, as well as water table depth and fluctuation.

The ability of a water balance equation (WBE) method to reveal and quantify unknown components of the hydrological cycle (e.g., sinkholes, faults, leaky layers, boundaries) in a high-evaporation setting, allows the development of accurate WBEs for (semi-)arid zone aquifers or plains with localized pockets of gypsum. Such pockets in the bedrock of a plain or aquifer call for novel groundwater modeling and WBE analysis, along with a good knowledge of subsurface conditions beneath the plain or aquifer, to determine and implement an appropriate and well-informed on-site remedial action and estimate its overall cost.

Typically, a few destructive boreholes are drilled, a geophysical study is undertaken and on occasion a few soil samples are also analyzed, offering WBE studies to have the potential to accurately simulate subsurface water recharge/discharge. Among the existing methods, WBE methods along with geophysical studies and analyses of borehole exploration logs are the most promising.

A basic mass balance equation widely used for quantifying groundwater recharge, the WBE constitutes one of the most basic methods in water resources management and hydrology. The WBE's water balance/budget considers strictly the volumes of water present at the outset, entering and leaving a regional- or local-scale three-dimensional space during a specific period of time (Fabbri et al., 2016). While tracer techniques, 
numerical models, and hydrological budgets can be used in water balance management, the simple water balance, while the most basic of methods, can provide fairly acceptable results. Other approaches may prove to be complex, time-consuming, or draw on data requiring sophisticated acquisition methods, making them a less than optimal approach for managers and hydrologists in the field (Manghi et al., 2009). One of most widely employed yet simplest methods of evaluating the groundwater budget is the water balance equation (WBE). The accuracy and the relevance of conclusions drawn through a WBE approach greatly depend on the accuracy of water balance components used in this method.

The water balance method applied in the present study is supported by the principle of conservation of mass (of water), as defined by the continuity equation given by Sokolov and Chapman (1974). In general, management and decision-making regarding the different water resource fractions of groundwater, surface water, and changes in groundwater storage are strongly dependent on the results of water balance analysis in an aquifer or basin (Todd and Mays, 2005).

By examining different water budget components, we can discover that irrigation may, for example, be the component most influential to aquifer recharge (Fabbri et al., 2016). Therefore, determining the levels of recharge and discharge of groundwater, as well as other effective factors on groundwater balance play a significant role in groundwater resources management, especially in semiarid areas such as Iran (Jafari et al., 2012; Lin et al., 2013).

The methods chosen in estimating and studying groundwater recharge (Scanlon et al., 2002), a critical component in the water balance, depends on the desired accuracy of the results, data availability and the complexity of the hydrogeological system (Wendland et al., 2007; Chenini and Kouzana, 2016). The methods range from simple analytical water balances to more complex numerical models (Wendland et al., 2007; Narasimhan, 2008; Manghi et al., 2009; Rayburg and Thoms, 2009; Calderhead et al., 2012; Praveena et al., 2012; Cao et al., 2013; Bocanegra et al., 2013; Wen et al., 2013; Mollema et al., 2013; Park et al., 2014; Maruyama et al., 2014; Mohammadi et al., 2014; Željković and Kadić, 2015; Tóth et al., 2016). Employing a mass-balance methodology, Portoghese et al. (2005) developed a geographic information system (GIS) model to estimate groundwater recharge in poorly gauged environments. Joodavi et al. (2016) evaluated groundwater recharge from hydrogeological inflow (e.g., infiltration, return flows and precipitation) in a complex alluvial-karst system. Raneesh and Thampi (2013) implemented the WBE in applied groundwater recharge models to quantify changes in groundwater level and water balance components. In a key study undertaken in southern Iran, Mohammadi et al. (2014) assessed groundwater recharge in a semi-arid system by using WBE to investigate the role of the Burazjan fault. They concluded that WBE constitutes an appropriate and sufficient approach to quantify known and specific unknown water balance components.

In the present study, a WBE approach took into account the role of local geology (e.g., chalky sinkholes in the alluvial sediments of the lower portion of the Golgir plain) along with that of the natural annual recharge of the alluvial aquifer. The study considered whether the presence of extraneous factors (e.g., sinkholes) influenced groundwater recharge or discharge in the Golgir plain. To our knowledge, this constitutes the first effort to employ a WEB as a simple, cost-effective, and easy-toapply approach to quantifying the role of sinkholes as an output component. 


\section{Study Area}

Located in southwestern Iran near the city of Masjed Soleyman, the Golgir plain (Fig. 1), with an expanse of $\approx 25 \mathrm{~km}^{2}$ situated between $49^{\circ} 26^{\prime} 45^{\prime \prime} \mathrm{E}-49^{\circ} 32^{\prime} 33^{\prime \prime} \mathrm{E}$ lat. and $31^{\circ} 43^{\prime} 20^{\prime \prime} \mathrm{N}-31^{\circ} 47^{\prime} 12^{\prime \prime} \mathrm{N}$ long., is the country's largest plain and alluvial aquifer. Elevations on the Golgir plain range from $246 \mathrm{~m}-390 \mathrm{~m}$ AMSL. The villages of Golgir, Bahramabad, Mohammadabad, Valyabad Sabzabad and Shamsabad are the most important towns on the plain.
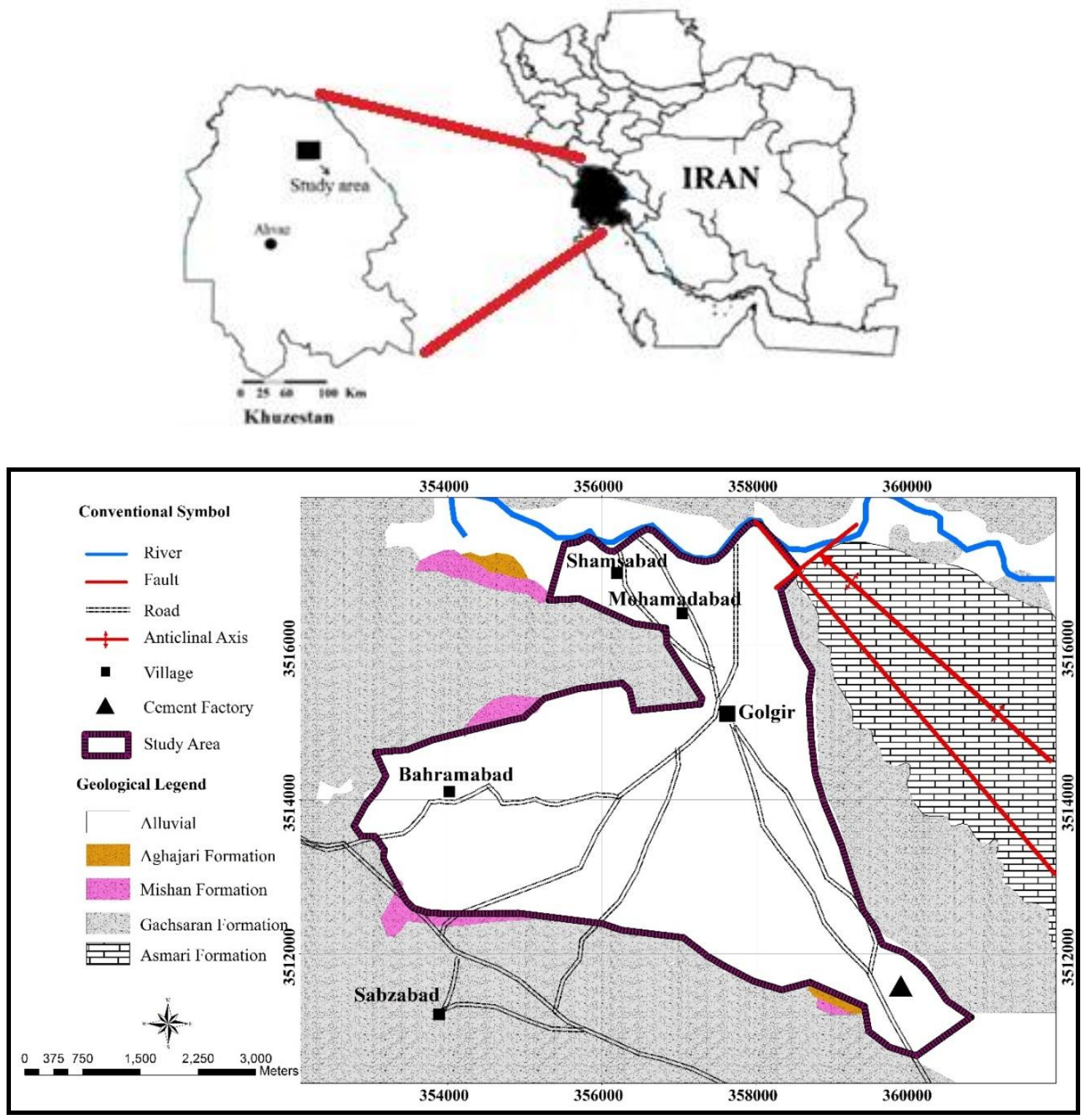

Figure 1. Geographic and geologic map of study area (Golgir plain, Iran)

The study area's climate is generally semi-arid, with dry summers and mild winters. Between 2005 and 2012, the annual mean maximum and minimum temperatures were $38^{\circ}$ and $12^{\circ} \mathrm{C}$, respectively, while annual mean precipitation and evaporation were 320 $\mathrm{mm}$ and $518 \mathrm{~mm}$, respectively (Ahvaz IRIMO, 2013). 
The Golgir region is an alluvial plain created predominantly by the erosion of the surrounding Asmari and Gachsaran formations which border the plain to the east and west, respectively. In general, the presence of chalky deposits in alluvium resulted in increased concentrations of sulfate and total dissolved solids in groundwater. The Gachsaran formation, which contributes the bedrock beneath the Golgir plain, bears anhydrite materials and chalky material, the latter of which contributes to the formation of active sinkholes which can act as water discharge sinks. The sinkholes presently active in this region causes a number of problems both in farming activities and groundwater management. For example, farmers lose water from extraction wells and attempt to replace it by increasing the well depth. In the study area, groundwater management issues became critical at the onset of the new millennium, with important damage being observed in the regions' extraction wells, farmland and roads.

\section{Geological Framework}

The study area is located in the Zagros Orogen, one of Iran's five structural zones (Alavi, 2004). Topographic maps, aerial photographs, geological maps (obtained from Khuzestan Department of Water and Power, 2013), field studies and Landsat $\mathrm{ETM}^{+}$satellite images (obtained from Usgs, 2013) were used to investigate the study area's geological characteristics. The Pabdeh formation (Oligocene-Eocene), the oldest formation in the region, includes shale, blue and dark green marls, along with a variety of thin layered clay limestone in its upper profile (Darvishzadeh, 1991). In the study area, the Pabdeh formation acts as a basement of karstification for the Asmari formation (Oligocene-Eocene). The Asmari formation consists of layers of soft, cream-colored limestone.

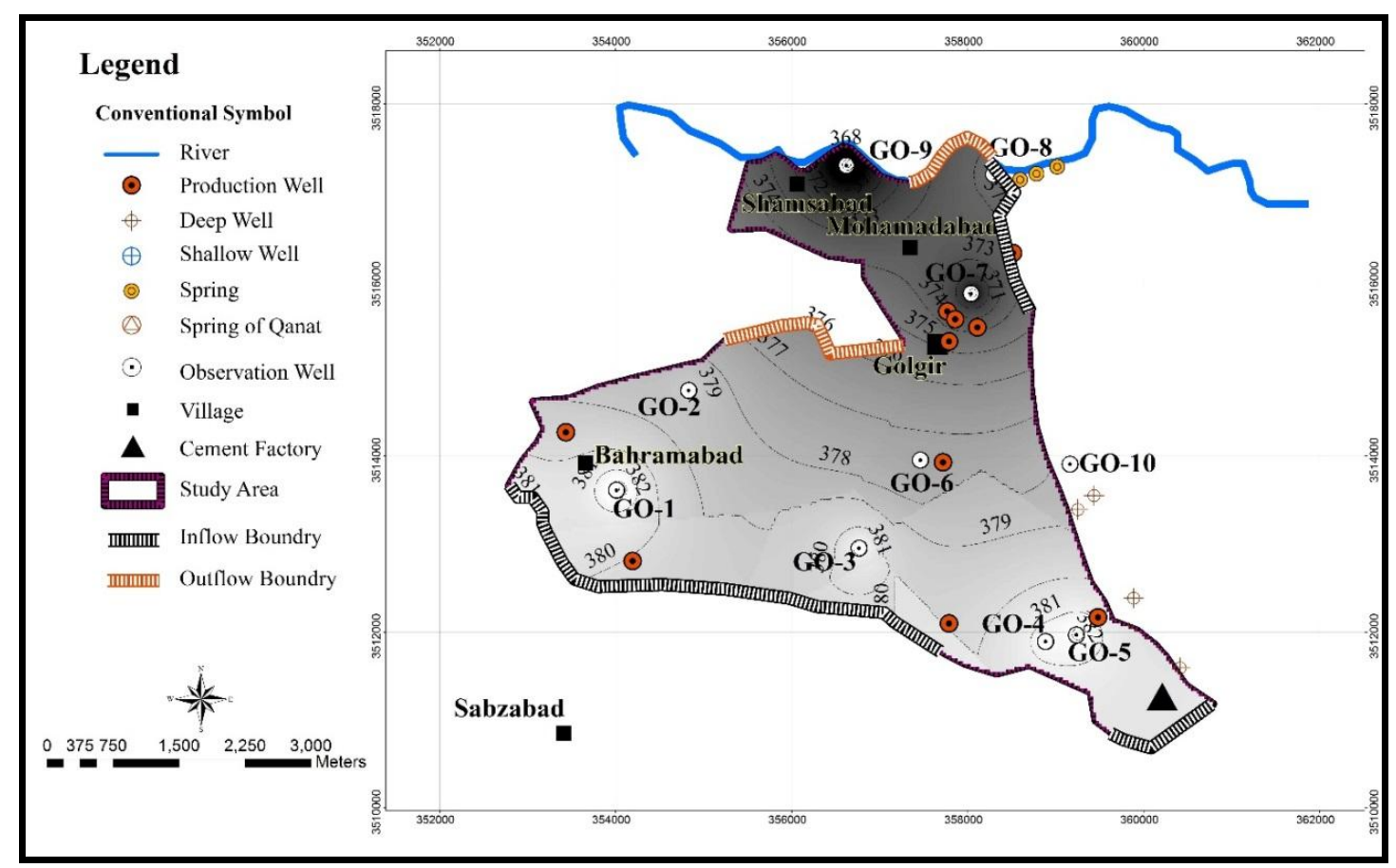

Figure 2. Hydrogeological and water resource map in Golgir plain, Iran 
The majority of precipitation infiltrates through a highly fractured zone into the karstic system. Contributing to a loss in groundwater quality in the study area, the Gachsaran formation (Miocene), which surrounds the Golgir plain to the North, South and West, consists of salt, anhydrite, colored-marls, limestone and some bituminous shale. Overall, the plain is surrounded by Asmari, Gachsaran, Mishan, and Aghajari geological formations. A hydrogeological and water resource map of the Golgir plain (Fig. 2), shows the general groundwater flow direction in the plain to be from the South and Southwest to the East and North, with the groundwater outlet located North of the plain.
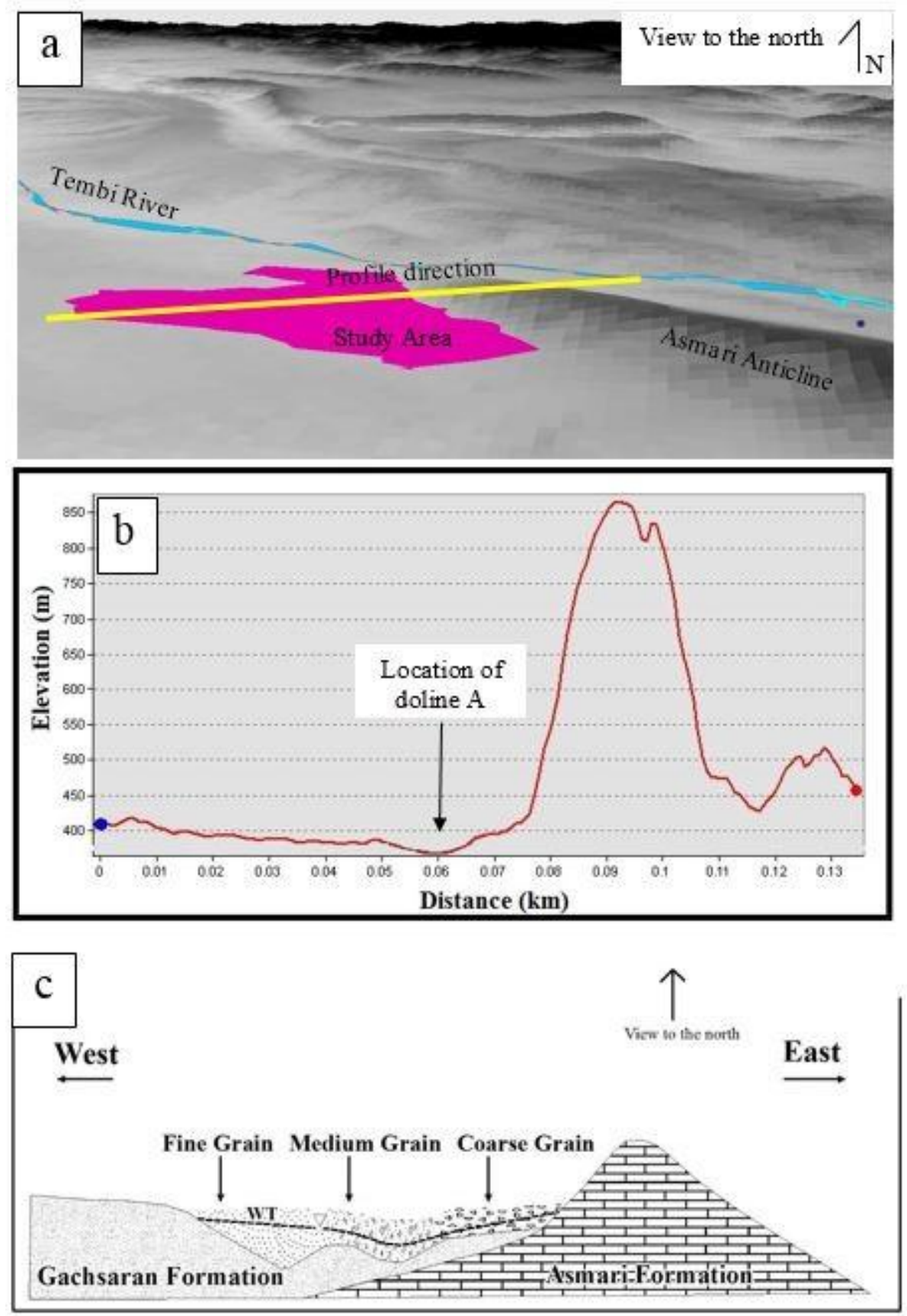

Figure 3. a) Digital elevation model image b) Location of sinkhole A in profile direction c) The schematic cross section of sedimentation process in the alluvium of study area (Golgir plain, Iran) 
Erosion of the Asmari formation has caused sedimentation in the form of gravel deposits along with some clay. Drilling logs show that as one moves away from the Asmari anticline from East to West, the volume of fine-grained sediments from erosion of the Gachsaran formation increases. Digital elevation model images, profile direction, and a schematic cross section of sedimentation process in the Golgir plain are presented in Fig. 3, Erosion of the Gachsaran formation caused increased deposition of silt and clay deposits and also led to the presence of sulfated minerals in the Golgir plain's alluviums.

\section{Hydrogeological Framework}

With a basin extending over roughly $2586 \mathrm{~km}^{2}$, the Temby (Shoor) River is the only river in the study area. Given its mean electrical conductivity (EC) of $25 \mathrm{mS} \mathrm{cm}^{-1}$, the Temby River's waters are practically unusable given their salinity. The study area includes two aquifers: (i) one of hard rock (limestone), composed of the Asmari formation and situated in the Asmari anticline, which extends roughly $27 \mathrm{~km}$ across the eastern portion of the Golgir plain and (ii) one alluvial, composed of limestone debris from the Asmari formation and plaster debris from the Gachsaran formation. The main sources of recharge are infiltration from precipitation, irrigation return flows and boundaries of the alluvial aquifer.

Evidence from the surface of the Asmari anticline indicates the development of karstification in the Asmari limestone aquifer. This alluvial aquifer ranges from $10 \mathrm{~m}$ to $100 \mathrm{~m}$ in thickness, with the greatest thickness occurring in the Southeastern portion of the plain. Eight years of monthly groundwater levels at 10 observation wells and piezometers were used in present study (Khuzestan Department of Water and Power, 2013). Hydraulic conductivity ranged from $1 \mathrm{~m} \mathrm{~d}^{-1}$ to $7 \mathrm{~m} \mathrm{~d}^{-1}$, while the specific yield (volume of aquifer water released from storage per surface area of aquifer per drop in the water table; $\mathrm{m}^{3} \mathrm{~m}^{-2} \mathrm{~m}^{-1}$ — Neuman, 1987; Todd and Mays, 2005) ranged from 0.08 to 0.20 .

\section{Theoretical Background}

The present study drew upon different data sources: surface observations of alluvial sinkholes (e.g., farmland depressions and sites of road subsidence), observations of outcrops on derelict depressions, a detailed cartography of variations in the Golgir plain over active sinkholes, as well as a compilation and analysis of physical and hydrological data.

The development of alluvial sinkholes is influenced by a number of factors (Soriano and Simon, 1995, 2002): (i) groundwater discharge through the bedrock (e.g., solubility, presence of penetrable coarse-sized particles, infiltration and flow), and (ii) the probability of subsidence of the cover as a result of groundwater discharge from the study area (e.g., lithology, geomechanical behavior, depth of the water table).

After reviewing the available information, evidence must be examined and gathered to identify alluvial sinkholes (i.e., the unknown component) by means of assessing their impact on the hydrogeological system. This can be done by: (i) using geophysical maps of the bedrock (Fig. 4), (ii) monitoring sudden changes in groundwater discharge in the wells, especially in the vicinity of alluvial sinkholes, (iii) noting the presence of a chalky rock basement prone to forming sinkholes (Fig. 5), (iv) noting sudden collapses of the bedrock on the order of $40 \mathrm{~m}$, (v) identifying the region's structural geology and 
how prone the region is to the formation of sinkholes, and (vi) noting drops in groundwater levels in piezometers and observational wells in the vicinity of alluvial sinkholes compared to other parts of the plain.
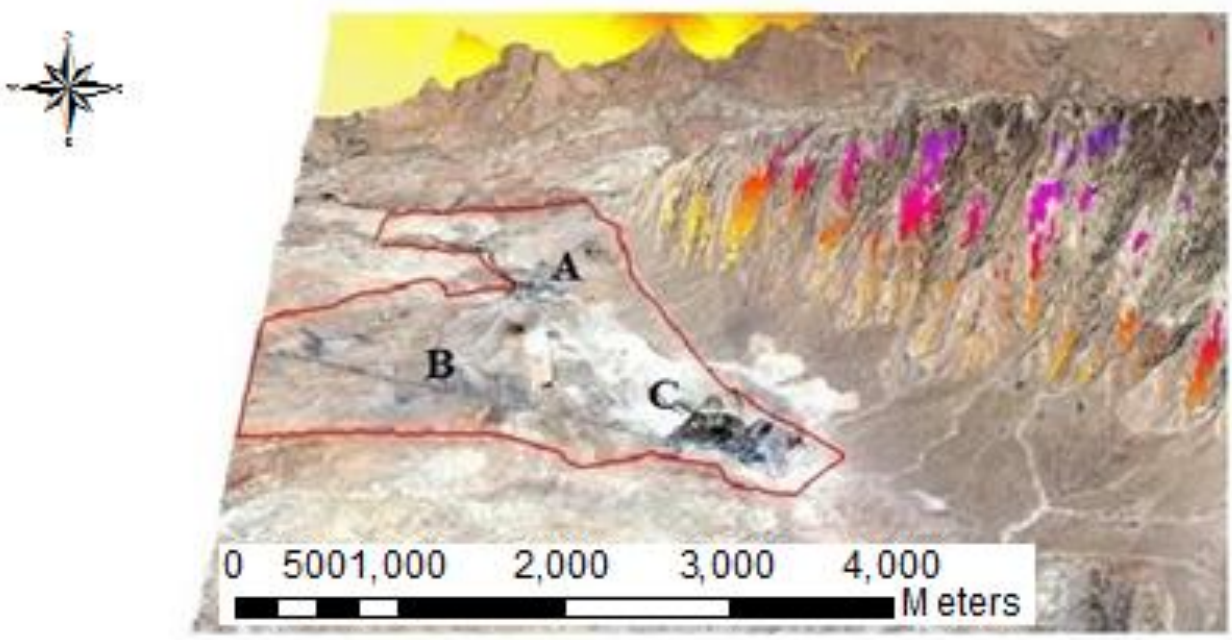

(a)
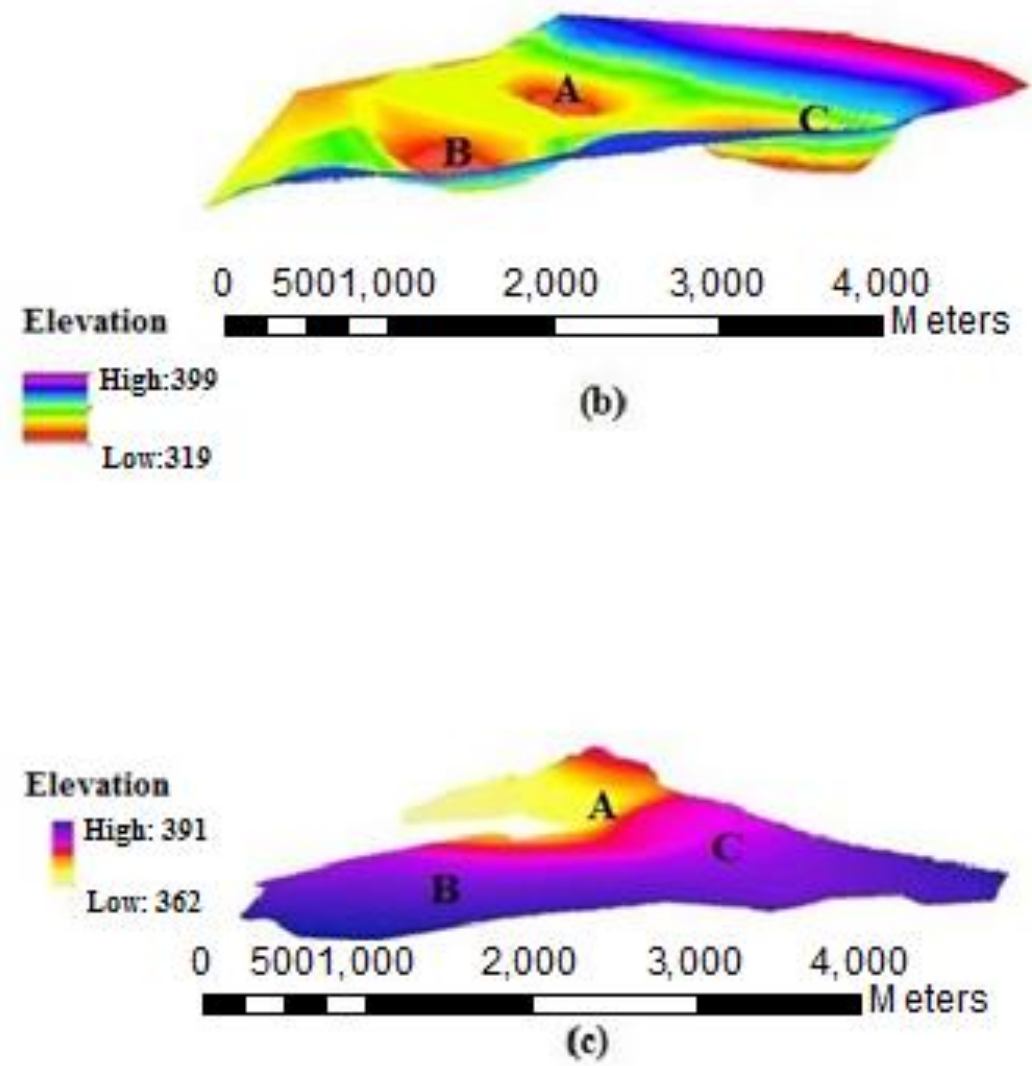

Figure 4. Three-dimensional images of bedrock and groundwater level in Golgir plain, Iran: a) 3D Satellite image b) geophysical map of bedrock c) groundwater level 


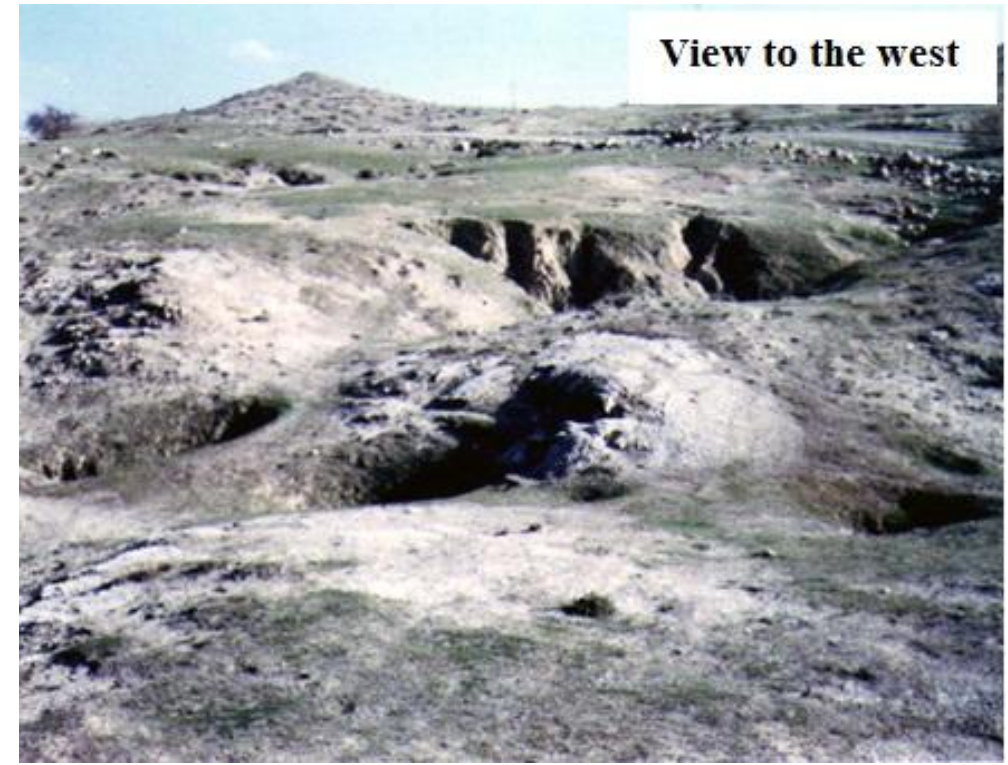

Figure 5. Sinkhole in the Gachsaran formation in Golgir plain, Iran

By studying fluctuations in groundwater level, groundwater level depression and logs of exploration wells located within the area of alluvial sinkholes (Fig. 6), the existence of clay in the alluvial deposits was confirmed. The existing clay in the alluvial deposits influences sinkhole activity in the subsoil through its control on the permeability of the cover. Fig. 6, shows that clay content within the alluvial sediments varied from about $5 \%$ in sinkhole A (Asmari formation sediments, lime debris and some sand), to $80 \%$ in sinkhole $\mathrm{C}$ (Gachsaran formation sediments, silt and clay). The area within sinkhole A, which showed the greatest sinkhole development coincided with the area bearing the least clay; therefore, the development of sinkholes in the region is clearly greater in regions with lesser clay content. The sudden decrease in the level of groundwater at sinkhole A seems to have mainly been caused by the output component (i.e., the sinkhole). The existing clay in the sedimentary sequence of alluvial sinkholes B and C, rendered these sinkholes inactive and closed water flow pathways.

Chalky alluvial sinkholes in the Golgir plain can be considered as a simple output component; therefore, application of the WBE can be effective in determining their role and hydrological performance. The plain's actual recharge, calculated incorrectly in prior studies due to a lack of knowledge can be corrected through a WBE-based assessment of sinkhole performance. However, before choosing a suitable method for the determination of groundwater recharge, many factors must be considered. Depending on data availability, the hydrological system in question, and the desired accuracy of results, several methods exist to estimate groundwater recharge (Scanlon et al., 2002; Wendland et al., 2007; Batelaan and DeSmedt, 2007). The first step in estimating groundwater recharge was to provide a basic conceptual model of the Golgir plain study area, allowing a better understanding of its hydrogeological behavior and water balance. 


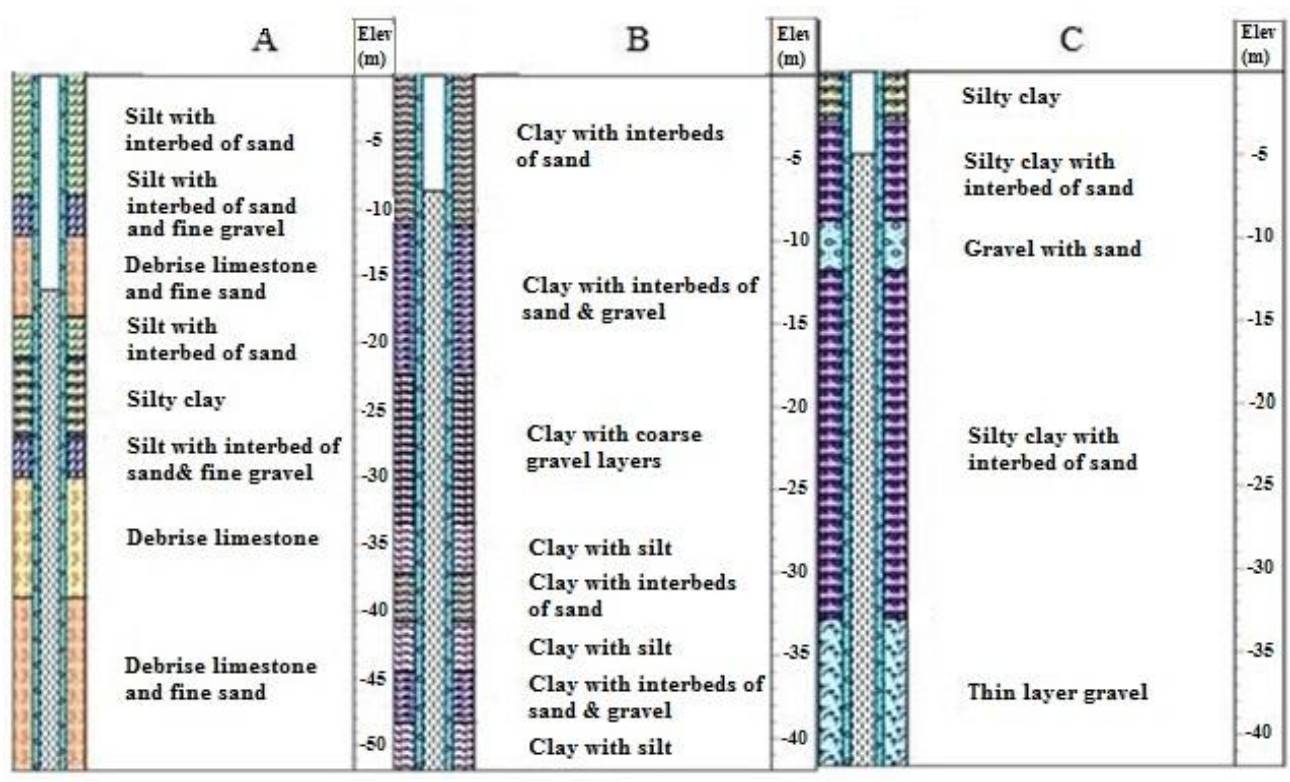

Figure 6. Exploration well logs located within the area of sinkhole

McWhorter and Sunada (1977) defined the overall WBE as follows:

$$
(\Sigma I-\Sigma O) \Delta t= \pm S
$$

where $\Sigma \mathrm{I}$ and $\Sigma \mathrm{O}$ are total input and total output from/to the aquifer, respectively, over a duration $\Delta \mathrm{t}$, and where $\Delta \mathrm{S}$ is the change in groundwater storage. The input and output components involved in the calculation of the balance for a given aquifer are:

$$
\Sigma I=I_{P}+I_{R}+I_{I R F}+I_{s w}+I_{G}
$$

and

$$
\Sigma O=O_{w}+O_{E T}+O_{G}+O_{D}
$$

where, $I_{P}, I_{R}, I_{I R F}$ and $I_{S W}$ are the infiltration volume from precipitation, runoff, irrigation, and from industry and domestic wells, respectively, and $\mathrm{O}_{\mathrm{W}}, \mathrm{O}_{\mathrm{ET}}$ and $\mathrm{O}_{\mathrm{D}}$ are outputs from the aquifer system arising from pumping, evapotranspiration and drainage into the river respectively. The parameters $\mathrm{I}_{\mathrm{G}}$ and $\mathrm{O}_{\mathrm{G}}$ are, respectively, the subsurface input and output of water from the aquifer boundaries. After determining the input and output components in the above equations, changes in groundwater storage $(\Delta S)$ can be calculated as (Bredehoeft et al., 1982):

$$
\Delta S=\Delta H \times A \times S_{y}
$$

where $\Delta \mathrm{H}$ is changes in groundwater level over a duration $\Delta \mathrm{t}, \mathrm{A}$ is the area of the aquifer and Sy is the specific yield of the aquifer. The groundwater balance can then be 
calculated, with the total recharge and discharge to/from the aquifer calculated by splitting Eq. 1 into two equations:

$$
\begin{gathered}
\Sigma O=\left(I_{P}+I_{R}+I_{I R F}+I_{s w}+I_{G}\right) \pm S \\
\Sigma I=\left(O_{w}+O_{E T}+O_{G}+O_{D}\right) \pm S
\end{gathered}
$$

These equations to estimate $\Sigma I$ and $\Sigma O$ can then serve: (i) in calculating the output or input components is particularly difficult, and ii) when the region's hydrogeology must be taken into consideration.

\section{Results}

Applying the WBE allows an effective identification of components in the water balance (Eq. 1), but necessitates the calculation of the input and output components of groundwater along with changes in groundwater storage, as well as sufficient understanding of the conceptual model and components affecting the Golgir plain's water balance. Faced with the Golgir plain's hydrologic and geological complexities, and the need to draw out information regarding the performance of the plain's flow components, the effective components of input/output flows as well as changes in groundwater aquifer storage were calculated.

\section{Output components ( $\Sigma O)$}

Data collected between 2005 and 2012 led to an estimate of the mean annual volume of water drawn from 18 extraction wells to be about $1.81 \times 10^{6} \mathrm{~m}^{3}$ (Table 1). To calculate the volume of water lost at the aquifer boundaries, Darcy's equation (Eq. 7), was used:

$$
\mathrm{V}=\mathrm{TLI} \mathrm{t}
$$

where the parameters T, L, I and $\Delta t$ represented transmissivity of the aquifer, the length of the output aquifer boundary, the hydraulic gradient and the duration over which the water balance was assessed, respectively. In order to measure the hydraulic gradient and flow output boundary length, output boundaries were specified (Fig. 2). Monthly changes in groundwater level were then assessed using GIS. Flow output volume on an annual basis is provided in Table 1 .

The evaporation from surfaces and transpiration from plants which occurs when sufficient water is available is termed potential evapotranspiration $\left(\mathrm{ET}_{\mathrm{p}}\right)$, whereas actual evapotranspiration $\left(\mathrm{ET}_{\mathrm{a}}\right)$ represents evapotranspiration under water-limiting conditions (Thornthwaite, 1948). Using the approach developed by Thornthwaite (1948), the study area's $\mathrm{ET}_{\mathrm{a}}$ was derived from monthly mean temperature and rainfall on the Golgir plain, and an estimate of the water needed for the growth of the dominant plants in the study area (Shaw et al., 2010). The final $\mathrm{ET}_{\mathrm{a}}$ values (Table 1) were calculated using the White Curve (White, 1932).

To determine the nature of the hydraulic interactions occurring between the river and the alluvial aquifer, field surveys and comprehensive studies were employed to determine the absence/presence and nature of such interactions. Analysis of field surveys, evidence from exposed springs, groundwater flow direction and satellite 
images indicated that, due to fault action and the presence of a thick clay layer in the soil, there was no hydraulic interaction between the plain and the river reaches situated in the Eastern portion of the plain. However, in the western portion of the plain contiguous with the river, the river drains the aquifer. Groundwater level changes visualized using GIS were employed in calculating outflow from the Golgir plain to the river. The volume of groundwater seepage into the river between 2005 and 2012 was calculated on a monthly basis (Eq. 7). The final calculated output components $(\Sigma \mathrm{O})$ ranged from $3.72 \times 10^{6} \mathrm{~m}^{3} \mathrm{y}^{-1}$ to $5.94 \times 10^{6} \mathrm{~m}^{3} \mathrm{y}^{-1}$, with an average of $4.78 \times 10^{6} \mathrm{~m}^{3} \mathrm{y}^{-1}$ (Table 1).

Table 1. The value of output components $\left(10^{6} \mathrm{~m}^{3} \mathrm{y}^{-1}\right)$ for Golgir plain in 2005 to 2012

\begin{tabular}{c|c|c|c|c|c}
\hline$\Delta \mathrm{t}($ year) & $\mathbf{O}_{\mathbf{G}}$ & $\mathbf{O}_{\mathbf{W}}$ & $\mathbf{O}_{\text {ET }}$ & $\mathbf{O}_{\mathbf{D}}$ & $\Sigma \mathrm{O}$ \\
\hline 2005 & 1.91 & 1.89 & 0.38 & 0.62 & 4.80 \\
2006 & 1.89 & 1.87 & 1.19 & 0.58 & 5.53 \\
2007 & 1.62 & 1.91 & 0.16 & 0.57 & 4.26 \\
2008 & 1.43 & 1.75 & 0.38 & 0.55 & 4.11 \\
2009 & 2.25 & 1.98 & 1.13 & 0.58 & 5.94 \\
2010 & 1.47 & 2.01 & 1.27 & 0.55 & 5.30 \\
2011 & 1.45 & 1.6 & 0.12 & 0.55 & 3.72 \\
2012 & 2.07 & 1.5 & 0.41 & 0.63 & 4.61 \\
Average & 1.76 & 1.81 & 0.63 & 0.58 & 4.78 \\
\hline
\end{tabular}

\section{Changes in water storage $(\Delta S)$}

In order to calculate changes in groundwater storage, it was necessary to calculate $\Delta \mathrm{H}$ and Sy (Eq. 4). Monthly groundwater levels in 10 observation wells were used in order to calculate the mean monthly groundwater level in the aquifer and assessed in ten sampling well-associated subregions of the plain developed in the GIS environment using Thiessen polygons. Monthly hydrographs of aquifer volume and rainfall depth over the study area (Fig. 7), served in calculating annual $\Delta \mathrm{H}$ in the aquifer.

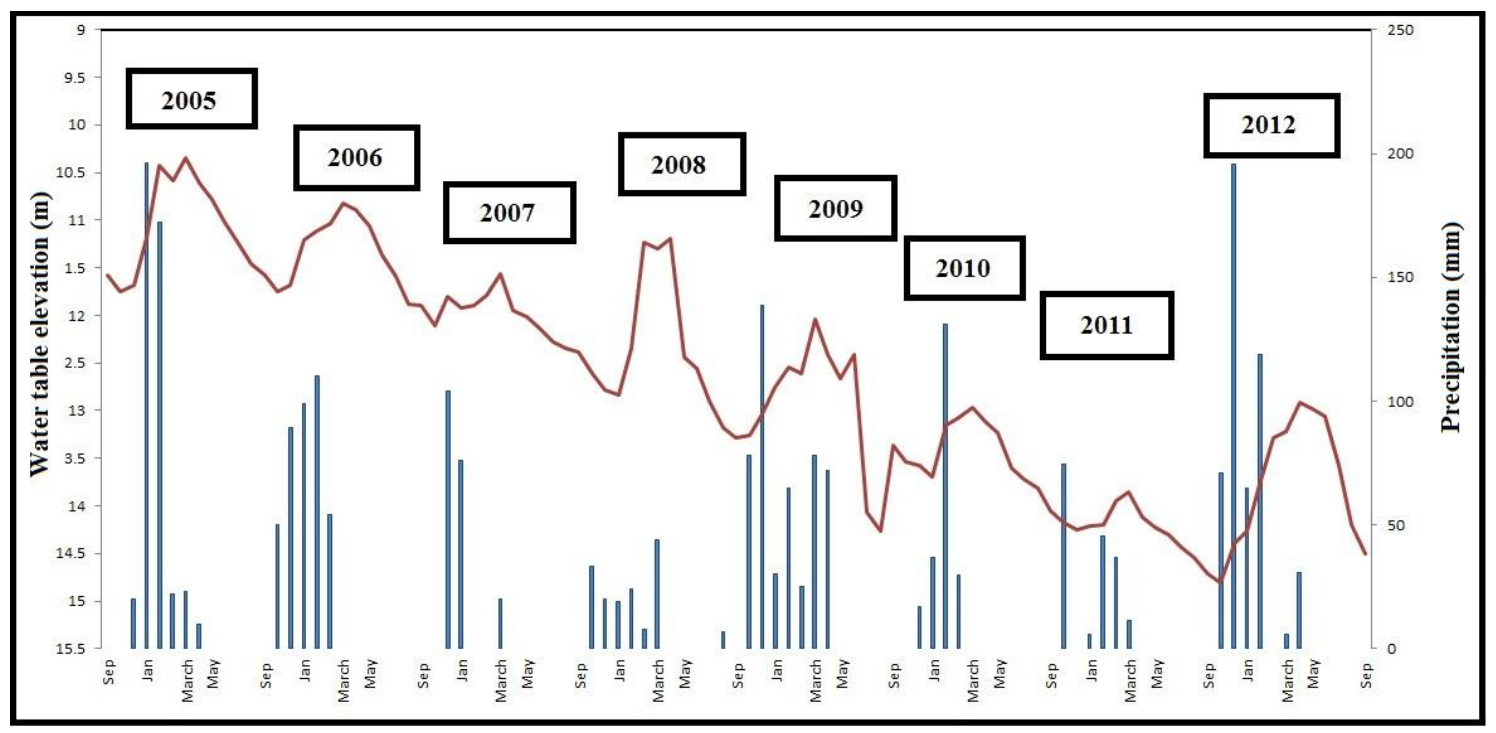

Figure 7. The hydrograph of aquifer and rainfall of study area (Golgir plain, Iran) 
Due to the porous nature of the aquifer, determination of a comprehensive value for specific yield (Sy) is difficult (Manghi et al., 2009). Based on the work of Varni et al. (2013) who developed an "Envelope Straight Line" (ESL) method to estimate mean Sy values for the Pampa plain, an ESL method was used to obtain Sy in the present study. Given the strong and direct relationship between rainfall and groundwater recharge, Sy values can be estimated by drawing a plot of precipitation vs. rise in groundwater level. In the present study, a Thiessen polygon method separating the plain into 10 sampling well-associated subregions served to enhance the accuracy of the analysis and to aid in calculating the results. For each polygon, the rise in groundwater level was plotted against effective rainfall over the study period of 2005 to 2012, in an effort to determine Sy values for each polygon. The largest specific yield was estimated for polygon GO-8 $(\mathrm{Sy}=0.20)$, and the lowest value for polygon GO-1 $(\mathrm{Sy}=0.08)$, with an overall weighted mean of 0.13 for the whole plain. Values of $\Delta S$ from 2005 to 2012 obtained using Eq. 4, ranged from $-3.35 \times 10^{6} \mathrm{~m}^{3} \mathrm{y}^{-1}$ to $0.16 \times 10^{6} \mathrm{~m}^{3} \mathrm{y}^{-1}$, with a mean value of $-1.69 \times 10^{6} \mathrm{~m}^{3} \mathrm{y}^{-1}$ (Table 2). Fig. 8 shows the relationship between effective rainfall and groundwater level rise across all polygons (GO-1 to GO-10).

\section{Input Components $(\Sigma I)$}

In order to calculate $I_{p}$, a double ring infiltration test was set up in three regions of the Golgir plain of known soil texture, and documented through satellite images and field surveys. Runoff was calculated based on the study of Mohammadi et al. (2014). The conceptual model used to determine the input (inflow to the plain) boundaries of flow and their length, along with $\mathrm{I}_{\mathrm{G}}$, was developed using the Darcy equation. To determine the input boundaries, a flow direction map and field surveys were carried out. The inflow boundaries were specified for two regions of the Golgir plain (Fig. 2). Agricultural return water flow, volume of water penetrating originating from industry and domestic wells, along with penetration percentage were estimated (Table 2). The $\Sigma \mathrm{I}$ was calculated to be within a range of $4.32 \times 10^{6} \mathrm{~m}^{3} \mathrm{y}^{-1}$ to $7.15 \times 10^{6} \mathrm{~m}^{3} \mathrm{y}^{-1}$, with an average of $5.64 \times 10^{6} \mathrm{~m}^{3} \mathrm{y}^{-1}$.

Table 2. Estimated discharge $\left(10^{6} \mathrm{~m}^{3} \mathrm{y}^{-1}\right)$ in Golgir plain in the years of 2005 to 2012

\begin{tabular}{c|c|c|c|c|c|c|c|c}
\hline$\Delta \mathbf{t}$ (year) & $\mathbf{I}_{\mathbf{G}}$ & $\mathbf{I}_{\mathbf{P}}$ & $\mathbf{I}_{\mathbf{I R F}}$ & $\mathbf{I}_{\mathbf{S W}}$ & $\mathbf{I}_{\mathbf{R}}$ & $\Sigma \mathbf{I}$ & $\Delta \mathbf{S}$ & $\Sigma \mathbf{O}$ \\
\hline 2005 & 3.56 & 1.86 & 0.22 & 0.79 & 0.07 & 6.50 & -0.67 & 7.17 \\
2006 & 3.46 & 1.69 & 0.23 & 0.80 & 0.07 & 6.25 & -1.34 & 7.59 \\
2007 & 3.11 & 0.84 & 0.20 & 0.77 & 0.03 & 4.95 & -2.34 & 7.29 \\
2008 & 2.66 & 0.65 & 0.20 & 0.79 & 0.03 & 4.32 & -0.33 & 4.65 \\
2009 & 3.66 & 2.04 & 0.22 & 0.79 & 0.08 & 6.79 & -2.68 & 9.47 \\
2010 & 2.86 & 0.90 & 0.20 & 0.79 & 0.04 & 4.78 & -3.35 & 8.13 \\
2011 & 2.47 & 0.73 & 0.24 & 0.92 & 0.03 & 4.39 & -2.98 & 7.37 \\
2012 & 3.84 & 2.05 & 0.25 & 0.94 & 0.08 & 7.15 & 0.16 & 6.99 \\
Average & 3.2 & 1.35 & 0.22 & 0.82 & 0.05 & 5.64 & -1.69 & 7.33 \\
\hline
\end{tabular}



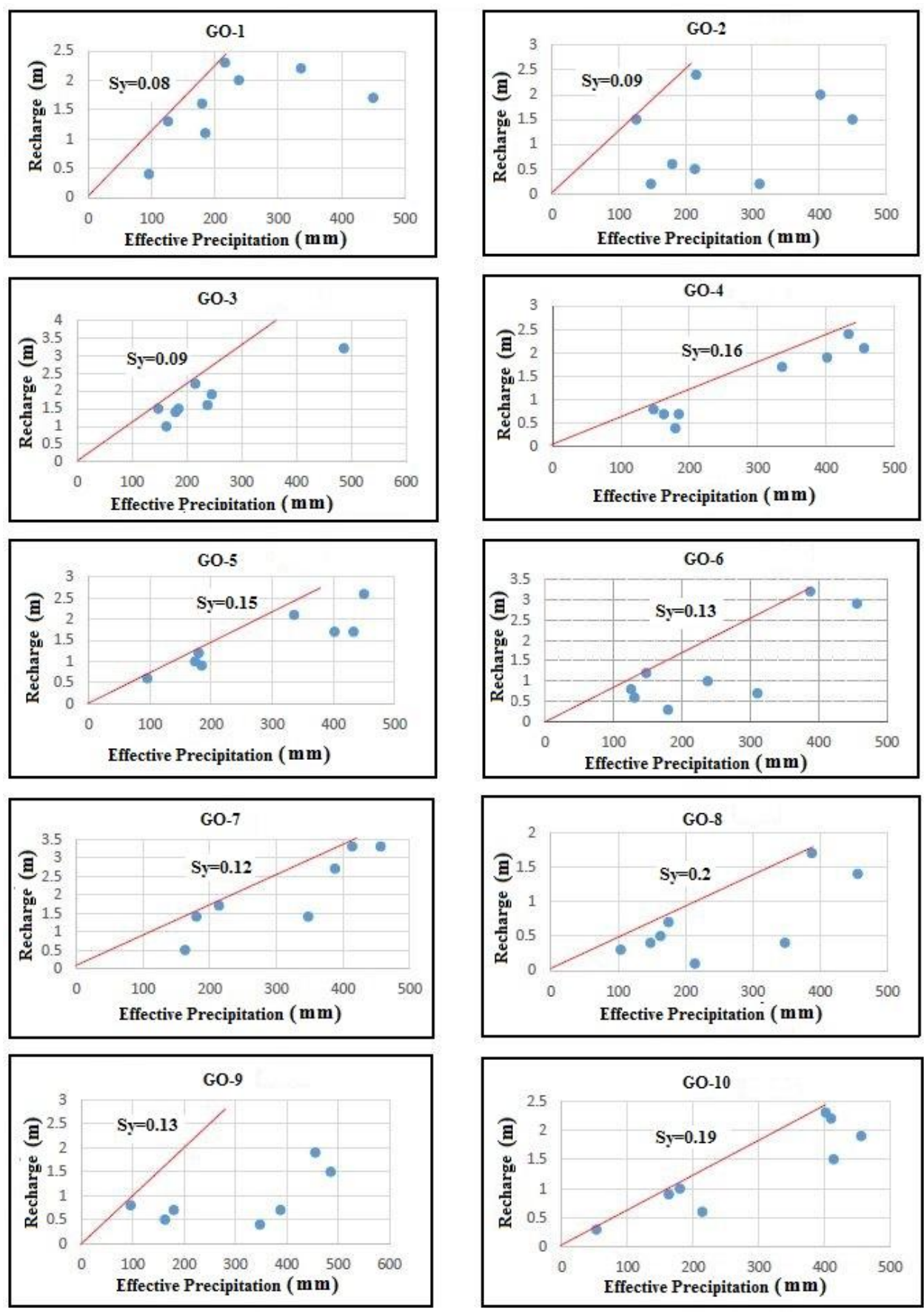

Figure 8. Relationship between effective rainfall and groundwater level rise

\section{Discussion}

The main objective of the present study was to evaluate the role of alluvial sinkholes in groundwater budget estimation using the WBE. The WBE indeed showed that there were unknown output components in the Golgir plain. With a greater understanding of the role of alluvial sinkholes and their output volume $\left(\mathrm{O}_{\text {Sinkhole }}\right)$, closer matches of water inputs and outputs were achieved in the WBE analysis, thereby minimizing underestimation errors or miscalculations of input components in estimating ground water recharge. 
Given that from 2005 to $2012 \Sigma \mathrm{I}>\Sigma \mathrm{O}$, the $\Delta \mathrm{S}$ supported a plausible assumption that errors occurred in calculating changes in aquifer storage. This left three possible explanations: (i) underestimation or error in the calculation of output flow components (about 25\%); (ii) overestimation or error in the calculation of flow input components, or (iii) a lack of understanding regarding unidentified output flow components. Comparing the $\Sigma \mathrm{O}$ obtained from Eq. 3, to that obtained with Eq. 5, showed a significant difference which averaged $2.55 \times 10^{6} \mathrm{~m}^{3} \mathrm{y}^{-1}$ (Tables 1 and 2).

Direct measurement of most of the components of the WBE is impossible, difficult or expensive to implement given a lack of knowledge of the presence and magnitude of output flow components; therefore, these components are estimated using secondary variables. In practice, there can be an at least $20 \%$ error in the calculation of certain components (Mohammadi et al., 2014); though, based on the present calculation of $\Sigma \mathrm{O}$, an error exceeding $20 \%$ should have occurred.

Evaluation of the effect of errors in the calculation and the determination of $\Sigma \mathrm{O}$ based on the WBE has been studied through sensitivity analysis (Hamby, 1994; Frey and Patil, 2002). Differential Analysis can be used to examine the effect of error in all components of the water balance, as well as on $\Sigma \mathrm{O}$ error, assuming $\Sigma \mathrm{O}$ to be dependent upon components of the WBE:

$$
\sum \mathrm{O}=f\left(\left[\mathrm{~S} \cdot \mathrm{O}_{\mathrm{W}} \cdot \mathrm{O}_{\mathrm{G}} \cdot \mathrm{O}_{\mathrm{ET}} \cdot \mathrm{I}_{\mathrm{IRF}} \cdot \mathrm{I}_{\mathrm{G}} \cdot \mathrm{I}_{\mathrm{P}} \cdot \mathrm{I}_{\mathrm{R}} \cdot \mathrm{I}_{\mathrm{SW}}\right)\right.
$$

Based on partial derivatives of $\Sigma O$ with respect to each and all components, differential analysis evaluated the effect of each components in determining $\Sigma \mathrm{O}$ (Table 3). This method uses Taylor series to develop a sensitivity analysis (Helton, 1993; Helton and Davis, 2003):

$$
Y(X)=f\left(x_{0}\right)+\sum_{j=1}^{x n}\left[\frac{\delta f\left(x_{0}\right)}{\delta x_{j}}\right]\left[x_{j}-x_{j_{0}}\right]
$$

where $\mathrm{Y}(\mathrm{X})$ is model prediction, $\mathrm{f}(\mathrm{x} 0)$ base value function, $\delta \mathrm{f}\left(\mathrm{x}_{0}\right)$ base value function differential, $x \mathrm{j}$ variable differential.

Table 3. Changes in terms of changes in the components of Eq. 5

\begin{tabular}{c|c|c|c|c|c|c|c|c|c}
\hline $\begin{array}{c}\text { Percent of error in } \\
\text { component of Eq. }\end{array}$ & $\mathbf{5}$ & $\mathbf{1 0}$ & $\mathbf{1 5}$ & $\mathbf{2 0}$ & $\mathbf{2 5}$ & $\mathbf{3 0}$ & $\mathbf{3 5}$ & $\mathbf{4 0}$ & $\mathbf{4 5}$ \\
\hline dOut flow $\left(10^{6} \mathrm{~m}^{3} \mathrm{y}^{-1}\right)$ & 0.13 & 0.26 & 0.38 & 0.51 & 0.64 & 0.77 & 0.89 & 1.02 & 1.15 \\
\hline
\end{tabular}

The calculated error for $\Sigma O$ in the WBE was $0.51 \times 10^{6} \mathrm{~m}^{3} \mathrm{y}^{-1}$, significantly lower than the average $\Sigma \mathrm{O}\left(2.55 \times 10^{6} \mathrm{~m}^{3} \mathrm{y}^{-1}\right)$ (Tables 1 and 2). Given that the probability for the mean $\Sigma \mathrm{O}$ was stronger than for the derived $\Sigma \mathrm{O}$, applying the average value of the output from the aquifer into the balance equation yielded a more balanced equation.

Based on the geology of the study area, a reduction in $\Sigma \mathrm{O}$ (Table 1) in comparison with $\Sigma \mathrm{O}$ (Table 2), one can conclude that the discrepancy in the output component relates to existing sinkholes in the plain's bedrock. In the Golgir plain in these situations, an output flow component called $\mathrm{O}_{\mathrm{Sh}}$ must be added to Eq. 3. The discharge calculated using Eq. 5, is consistent with the assumption of the role of the sinkhole 
output in the plain. The magnitude of addition of annual $\mathrm{O}_{\mathrm{Sh}}$ necessary to add the water output from the sinkhole and establish equilibrium in the WBE was estimated to range between $0.54 \times 10^{6} \mathrm{~m}^{3} \mathrm{y}^{-1}$ and $3.53 \times 10^{6} \mathrm{~m}^{3} \mathrm{y}^{-1}$, with an average of $2.25 \times 10^{6} \mathrm{~m}^{3} \mathrm{y}^{-1}$ (Table 4). Comparison of $\mathrm{O}_{\mathrm{Sh}}$ with other output components of the recharge process highlights the important role of sinkhole outputs in the Golgir plain's bedrock.

Table 4. The estimated value $\left(10^{6} \mathrm{~m}^{3} \mathrm{y}^{-1}\right)$ of output from the plain by using Eq. 3 and Eq. 5

\begin{tabular}{c|c|c|c}
\hline$\Delta \mathbf{t}$ (year) & Result of Table 3 & Result of Table 1 & $\boldsymbol{O}_{\boldsymbol{S h}}$ \\
\hline 2005 & 7.60 & 4.80 & 2.37 \\
2006 & 7.45 & 5.53 & 2.06 \\
2007 & 7.05 & 4.26 & 3.03 \\
2008 & 4.62 & 4.11 & 0.54 \\
2009 & 9.19 & 5.94 & 3.53 \\
2010 & 7.78 & 5.30 & 2.83 \\
2011 & 7.03 & 3.72 & 3.65 \\
2012 & 7.00 & 4.61 & 2.38 \\
Average & 7.22 & 4.78 & 2.55 \\
\hline
\end{tabular}

\section{Conclusions}

The main objective of the present study was to assess the role of alluvial sinkholes in estimations of the groundwater budget using a WBE. The application of WBE to estimate net groundwater recharge and the recognition of other components affecting on groundwater discharge resulted in the heightened calculation accuracy. Calculation of the WBE in each year showed significant differences between: (i) the sum of known components of output flow and (ii) the sum of recharge and changes in groundwater storage. In general, the differences in the calculated values for groundwater output from sinkholes was estimated to be in a range of $0.54 \times 10^{6} \mathrm{~m}^{3} \mathrm{y}^{-1}$ to $3.53 \times 10^{6} \mathrm{~m}^{3} \mathrm{y}^{-1}$, with an average of $2.55 \times 10^{6} \mathrm{~m}^{3} \mathrm{y}^{-1}$. Assuming the acceptability of some error in the calculation of recharge components and changes in groundwater storage, there remained two debatable issues: (i) errors in the calculation of the output components, and (ii) the role of unknown output components (e.g., alluvial sinkholes). Geological and hydrogeological evidence in the study area's bedrock confirms the presence of sinkholes and their significant role in sharp drops in the groundwater table. Finally, the net recharge of groundwater from 2005 to 2012 was estimated to be $4.39 \times 10^{6} \mathrm{~m}^{3} \mathrm{y}^{-1}$ to $7.15 \times 10^{6} \mathrm{~m}^{3} \mathrm{y}^{-1}$, with an average of $5.64 \times 10^{6} \mathrm{~m}^{3} \mathrm{y}^{-1}$.

The WBE could therefore be consider as an easy to apply, reliable and cost-effective approach to ascertaining the nature of unknown components of the groundwater budget (e.g., sinkholes) in developing countries, where available data are somewhat limited.

Acknowledgment. Saeed Tourk-Qashqainejad and Manouchehr Chitsazan acknowledge the Khuzestan Department of Water and Power and I.R.I.M.O for providing some part of data.

\section{REFERENCES}

[1] Ahvaz I. R. I. M. O. (2013): Iranian Meteorological Office Data Processing Center. Islamic Republic of Iran Meteorological Office, Ahvaz, Iran 
[2] Alavi, M. (2004): Regional stratigraphy of the Zagros fold-thrust belt of Iran and its proforeland evolution. - American Journal of Science 304(1): 1-20.

[3] Bain, R. E. S., Wright, J. A., Christenson, E., Bartram, J. K. (2014): Rural: urban inequalities in post 2015 targets and indicators for drinking-water. - Science of the Total Environment 490: 509-513.

[4] Batelaan, O., De Smedt, F. (2007): GIS-based recharge estimation by coupling surfacesubsurface water balances. - Journal of Hydrology 337(3-4): 337-355.

[5] Bocanegra, E., Londono, O. Q., Martínez, D. E., Romanelli, A. (2013): Quantification of the water balance and hydrogeological processes of groundwater-lake interactions in the Pampa Plain, Argentina. - Environmental earth sciences 68(8): 2347-2357.

[6] Bredehoeft, J. D., Papadopulos, S. S., Cooper, H. H. (1982): Groundwater: the water budget myth. 51-57. In: Studies in geophysics: Scientific Basis of Water Resource Management. - Washington, D.C.: National Academy Press.

[7] Calderhead, A. I., Martel, R., Garfias, J., Rivera, A., Therrien, R. (2012): Pumping dry: an increasing groundwater budget deficit induced by urbanization, industrialization, and climate change in an over-exploited volcanic aquifer. - Environmental Earth Sciences 66(7): 1753-1767.

[8] Cao, G., Zheng, C., Scanlon, B. R., Liu, J., Li, W. (2013): Use of flow modeling to assess sustainability of groundwater resources in the North China Plain. - Water Resources Research 49(1): 159-175.

[9] Chenini, I., Kouzana, L. (2014): Comment on "Assessment of groundwater recharge in a semi-arid groundwater system using water balance equation, southern Iran" by Mohammadi et al. [J. Afr. Earth Sci. 95 (2014) 1-8]. - Journal of African Earth Sciences 118: 313-314.

[10] Frey, H., C., Patil, S. R. (2002): Identification and review of sensitivity analysis methods. - Risk Analysis 22(3): 553-578.

[11] Darvishzadeh, A. (1991): Geology of Iran. - Danesh-E-Emrouz pub., Teheran, 901pp. (In Persian).

[12] Fabbri, P., Piccinini, L., Marcolongo, E., Pola, M., Conchetto, E., Zangheri, P. (2016): Does a change of irrigation technique impact on groundwater resources? A case study in Northeastern Italy. - Environmental Science \& Policy 63: 63-75.

[13] Festa, V., Tripaldi, S., Siniscalchi, A., Acquafredda, P., Fiore, A., Mele, D., Romano, G. (2016): Geoelectrical resistivity variations and lithological composition in coastal gypsum rocks: A case study from the Lesina Marina area (Apulia, southern Italy). Engineering Geology 202: 163-175.

[14] Ford, D., Williams, P. D. (2013): Karst Hydrogeology and Geomorphology. - New York: John Wiley \& Sons.

[15] Girman, J., VanderGun, J., Haie, N., Hirata, R., Lipponen, A., Lopez-Gunn, E., Neupane, B., Shah, T., Vrba, J., Wallin, B. (2007): Groundwater Resources Sustainability Indicators, IHP-VI, Series on Groundwater No. 14. UNESCO, Paris. Seen 15 October 2016 at: http://unesdoc.unesco.org/images/0014/001497/149754e.pdf

[16] Gündoğan, İ., Helvacı, C., Sözbilir, H. (2008): Gypsiferous carbonates at Honaz Dağı (Denizli): First documentation of Triassic gypsum in western Turkey and its tectonic significance. - Journal of Asian Earth Sciences 32(1): 49-65.

[17] Gündogan, I., Önal, M., Depçi, T. (2005): Sedimentology, petrography and diagenesis of Eocene Oligocene evaporites: the Tuzhisar Formation, SW Sivas Basin, Turkey. - Journal of Asian Earth Sciences 25(5): 791-803.

[18] Hamby, D. M., (1994): A review of techniques for parameter sensitivity analysis of environmental models. - Environmental Monitoring and Assessment 32(2): 135-154.

[19] Helton, J. C., Davis, F. J. (2003): Latin hypercube sampling and the propagation of uncertainty in analyses of complex systems. - Reliability Engineering \& System Safety 81(1): 23-69. 
[20] Helton, J. C. (1993): Uncertainty and sensitivity analysis techniques for use in performance assessment for radioactive waste disposal. - Reliability Engineering \& System Safety 42(2-3): 327-367.

[21] Hildyard, R. C., Prior, D. J., Faulkner, D. R., Mariani, E. (2009): Microstructural analysis of anhydrite rocks from the Triassic Evaporites, Umbria-Marche Apennines, Central Italy: An insight into deformation mechanisms and possible slip systems. - Journal of Structural Geology 31(1): 92-103.

[22] Jafari, H., Raeisi, E., Hoehn, E., Zare, M. (2012): Hydrochemical characteristics of irrigation return flow in semi-arid regions of Iran. - Hydrological Sciences Journal 57(1): 173-185.

[23] Jiang, Y., Wu, Y., Groves, C., Yuan, D., Kambesis, P. (2009): Natural and anthropogenic factors affecting the groundwater quality in the Nandong karst underground river system in Yunan, China. - Journal of Contaminant Hydrology 109(1-4): 49-61.

[24] Joodavi, A., Zare, M., Raeisi, E., Ahmadi, M. B. (2016): A multi-compartment hydrologic model to estimate groundwater recharge in an alluvial-karst system. - Arabian Journal of Geosciences 9: 195.

[25] Khuzestan Department of Water and Power. (2005): Studies on recognition of groundwater in Golgir plain region. - New Earth Analysts Consultant.

[26] Lin, H. T., Ke, K. Y., Tan, Y. C., Wu, S. C., Hsu, G., Chen, P. C., Fang, S. T. (2013): Estimating pumping rates and identifying potential recharge zones for groundwater management in multi-aquifers system. - Water Resources Management 27(9): 3293-3306.

[27] Manghi, F., Mortazavi, B., Crother, C., Hamdi, M. R. (2009): Estimating regional groundwater recharge using a hydrological budget method. - Water Resources Management 23(12): 2475-2489.

[28] Maruyama, T., Noto, F., Yoshida, M., Horino, H., Nakamura, K. (2014): Analysis of water balance in the Tedori River alluvial fan areas of Japan: focused on quantitative analysis of groundwater recharge from river and ground surface, especially paddy fields. Paddy and Water Environment 12(1): 163-171.

[29] McWhorter, D. B., Sunada, D. K. (1977): Ground-water Hydrology and Hydraulics. Highlands Ranch, CO, USA: Water Resources Publications, LLC.

[30] Mohammadi, Z., Salimi, M., Faghih, A. (2014): Assessment of groundwater recharge in a semi-arid groundwater system using water balance equation, southern Iran. - Journal of African Earth Sciences 95: 1-8.

[31] Mollema, P. N., Antonellini, M., Gabbianelli, G., Galloni, E. (2013): Water budget management of a coastal pine forest in a Mediterranean catchment (Marina Romea, Ravenna, Italy). - Environmental Earth Sciences 68(6): 1707-1721.

[32] Narasimhan, T. N. (2008): A note on India's water budget and evapotranspiration. Journal of Earth System Science 117(3): 237-240.

[33] Neuman, S. P. (1987): On methods of determining specific yield. - Ground Water 25(6): 679-684.

[34] Park, C., Seo, J., Lee, J., Ha, K., Koo, M. H. (2014): A distributed water balance approach to groundwater recharge estimation for Jeju volcanic island, Korea. Geosciences Journal 18(2): 193-207.

[35] Portoghese, I., Uricchio, V., Vurro, M. (2005): A GIS tool for hydrogeological water balance evaluation on a regional scale in semi-arid environments. - Computers \& Geosciences 31(1): 15-27.

[36] Praveena, S. M., Abdullah, M. H., Bidin, K., Aris, A. Z. (2012): Sustainable groundwater management on the small island of Manukan, Malaysia. - Environmental Earth Sciences 66(3): 719-728.

[37] Raneesh, K. Y., Thampi, S. G. (2013): A simple semi-distributed hydrologic model to estimate groundwater recharge in a humid tropical basin. - Water Resources Management 27(5): 1517-1532. 
[38] Rayburg, S., Thoms, M. (2009): A coupled hydraulic-hydrologic modelling approach to deriving a water balance model for a complex floodplain wetland system. - Hydrology Research 40(4): 364-379.

[39] Scanlon, B. R., Healy, R. W., Cook, P. G. (2002): Choosing appropriate techniques for quantifying groundwater recharge. - Hydrogeology Journal 10 (1): 18-39.

[40] Schreiber, B. C., Babel, M., Lugli, S. (2007): Introduction and Overview. - In: Schreiber, B.C., Lugli, S., Babel, M. (Eds.) Evaporites Through Space and Time. Geological Society, London, Special Publications 285: 1-13.

[41] Shaw, E. M., Beven, K. J., Chappell, N. A., Lamb, R. (2010): Hydrology in Practice. Boca Raton, FL: CRC Press.

[42] Sokolov, A. A., Chapman, T. G. (eds.) (1974): Methods for water balance computations; an international guide for research and practice. A contribution to the International Hydrological Decade. - Paris: UNESCO Press. Seen 15 October 2016 at: http://unesdoc.unesco.org/images/0001/000115/011523eo.pdf

[43] Soriano, M. A., Simón, J. (1995): Alluvial sinkholes in the central Ebro Basin, Spain: a spatial and developmental hazard analysis. - Geomorphology 11(4): 295-309.

[44] Soriano, M., Simon, J. (2002): Subsidence rates and urban damages in alluvial sinkholes of the central Ebro Basin (NE Spain). - Environmental Geology 42(5): 476-484.

[45] Testa, G., Lugli, S. (2000): Gypsum-anhydrite transformations in Messinian evaporites of central Tuscany (Italy). - Sedimentary Geology 130(3): 249-268.

[46] Thornthwaite, C. W. (1948): An approach toward a rational classification of climate. Geographical Review 38(1): 55-94.

[47] Todd, K. D., Mays, L. W. (2005): Groundwater Hydrology, 3rd ed. - Hoboken, NJ: John Wiley \& Sons.

[48] Tóth, G., Rman, N., Ágnes, R. S., Kerékgyártó, T., Szőcs, T., Lapanje, A., Nádor, A. (2016): Transboundary fresh and thermal groundwater flows in the west part of the Pannonian Basin. - Renewable and Sustainable Energy Reviews 57: 439-454.

[49] Varni, M., Comas, R., Weinzettel, P., Dietrich, S. (2013): Application of the water table fluctuation method to characterize groundwater recharge in the Pampa plain, Argentina. Hydrological Sciences Journal 58(7): 1445-1455.

[50] Wen, L., Macdonald, R., Morrison, T., Hameed, T., Saintilan, N., Ling, J. (2013): From hydrodynamic to hydrological modelling: Investigating long-term hydrological regimes of key wetlands in the Macquarie Marshes, a semi-arid lowland floodplain in Australia. Journal of Hydrology 500: 45-61.

[51] Wendland, E., Barreto, C. E. A. G., Gomes, L. H. (2007): Water balance in the Guarani Aquifer outcrop zone based on hydrogeologic monitoring. - Journal of Hydrology 342(3): 261-269.

[52] White, W. N. (1932): A method of estimating ground-water supplies based on discharge by plants and evaporation from soil: Results of investigations in Escalante Valley, Utah. Unites States Geological Survey Water Supply Paper 659. Washington, D.C.: U.S. Department of the Interior, Geological Survey. Seen 15 October 2016 at: https://pubs.usgs.gov/wsp/0659a/report.pdf

[53] Željković, I., Kadić, A. (2015): Groundwater balance estimation in karst by using simple conceptual rainfall-runoff model. - Environmental Earth Sciences 74(7): 6001-6015. 